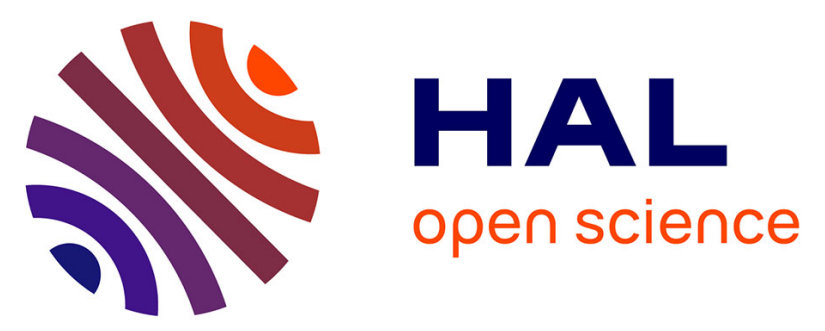

\title{
Understanding the skin sensitization capacity of ascaridole: a combined study of chemical reactivity and activation of the innate immune system (dendritic cells) in the epidermal environment
}

Fatma Sahli, Marta Silva E. Sousa, Bertrand Vileno, Jutta Lichter, Jean-Pierre Lepoittevin, Brunhilde Blömeke, Elena Giménez-Arnau

\section{To cite this version:}

Fatma Sahli, Marta Silva E. Sousa, Bertrand Vileno, Jutta Lichter, Jean-Pierre Lepoittevin, et al.. Understanding the skin sensitization capacity of ascaridole: a combined study of chemical reactivity and activation of the innate immune system (dendritic cells) in the epidermal environment. Archives of Toxicology, 2019, 10.1007/s00204-019-02444-3 . hal-02119633

\section{HAL Id: hal-02119633 \\ https://hal.science/hal-02119633}

Submitted on 3 May 2019

HAL is a multi-disciplinary open access archive for the deposit and dissemination of scientific research documents, whether they are published or not. The documents may come from teaching and research institutions in France or abroad, or from public or private research centers.
L'archive ouverte pluridisciplinaire HAL, est destinée au dépôt et à la diffusion de documents scientifiques de niveau recherche, publiés ou non, émanant des établissements d'enseignement et de recherche français ou étrangers, des laboratoires publics ou privés. 


\section{Understanding the skin sensitization capacity of ascaridole: a combined study of chemical reactivity and activation of the innate immune system (dendritic cells) in the epidermal environment}

Fatma Sahli, ${ }^{1}$ Marta Silva e Sousa, ${ }^{2}$ Bertrand Vileno, ${ }^{3,4}$ Jutta Lichter, ${ }^{2}$ Jean-Pierre Lepoittevin, ${ }^{1}$ Brunhilde Blömeke, ${ }^{2}$ Elena Giménez-Arnau ${ }^{1}$

${ }^{1}$ Dermatochemistry Laboratory, University of Strasbourg, CNRS UMR 7177, Institut le Bel, Strasbourg, France

${ }^{2}$ Department of Environmental Toxicology, University Trier, Germany

${ }^{3}$ POMAM Laboratory, University of Strasbourg, CNRS UMR 7177, Institut le Bel, Strasbourg, France

${ }^{4}$ French EPR Federation of Research, REseau NAtional de Rpe interDisciplinaire, RENARD, Fédération IR-RPE CNRS 3443, Strasbourg, France

\section{Corresponding Authors:}

Elena Giménez-Arnau

e-mail: egimenez@unistra.fr

Tel: +33368 851525

Brunhilde Blömeke

e-mail: bloemeke@uni-trier.de

Tel: +49 6512013782

ORCID iD

Elena Giménez-Arnau: https://orcid.org/0000-0001-8275-5447

Brunhilde Blömeke: https://orcid.org/0000-0002-3625-0701 


\begin{abstract}
To improve the prediction of the possible allergenicity of chemicals in contact with the skin, investigations of upstream events are required to better understand the molecular mechanisms involved in the initiation of allergic reactions. Ascaridole, one of the compounds responsible for skin sensitization to aged tea tree oil, degrades into intermediates that evolve via different mechanisms involving radical species. We aimed at broadening the knowledge about the contribution of radical intermediates derived from ascaridole to the skin sensitization process by assessing the reactivity profile towards amino acids, identifying whether free radicals are formed in a reconstructed human epidermis (RHE) model and their biological properties to activate the immune system, namely dendritic cells in their natural context of human HaCaT keratinocytes and RHE. Electron paramagnetic resonance combined to spin-trapping in EpiSkin ${ }^{\mathrm{TM}}$ RHE confirmed the formation of C-radicals in the epidermal tissue from $10 \mathrm{mM}$ ascaridole concentration, while reactivity studies toward amino acids showed electrophilic intermediates issued from radical rearrangements of ascaridole as the main reactive species. Activation of THP-1 cells, as surrogate for dendritic cells, that were cocultured with $\mathrm{HaCaT}$ was significantly upregulated after treatment with low micromolar concentrations based on cell surface expression of the co-stimulatory molecule CD86 and the adhesion molecule CD54. Placing THP-1 cells underneath the RHE allowed us to monitor which of the concentrations that produce radical(s) and/or protein antigens in the epidermal skin environment promote the activation of dendritic cells. We detected no significant upregulation of CD86/CD54 after topical RHE application of concentrations up to $30 \mathrm{mM}$ ascaridole $(\mathrm{t}=24 \mathrm{~h})$ but clear upregulation after $60 \mathrm{mM}$.
\end{abstract}

\title{
Keywords
}

Skin sensitization, dendritic cell activation, THP-1 cells, keratinocytes, ascaridole, reactivity, EPRspectroscopy, spin-trapping, reconstructed human epidermis 


\section{Introduction}

Allergic contact dermatitis (ACD) is the clinically relevant outcome of skin sensitization, one of the most important occupational and environmental health issues associated with chemicals. It is a delayedtype hypersensitivity reaction caused by a wide range of reactive chemicals referred to as contact allergens, natural or synthetic man-made, after repeated contact with the skin (Lepoittevin 2011). ACD is considered the most frequent expression of immunotoxicity in humans (Pesonen et al. 2015) and its prevalence is rising worldwide. The risk of skin sensitization resulting from exposure to allergens present in consumer products is a major regulatory issue within industry. It is thus crucial to predict the sensitization potential of chemicals and therefore perform reliable risk assessment before their introduction to the market. In this context, fundamental upstream investigations are required aiming at understanding molecular mechanisms involved in allergic-inflammatory reactions induced by sensitizers to cover all categories of molecules for risk assessment.

Ascaridole (Asc) is considered to be one of the compounds responsible for ACD to tea tree oil (TTO). Fresh TTO is a weak-moderate sensitizer (SCCP 2008) but air exposure leads to a 3-fold increase in its sensitization potential (Hausen et al. 1999). In the presence of atmospheric oxygen, the TTO constituents $\alpha$-terpinene, $\gamma$-terpinene and terpinolene are oxidized to $p$-cymene, which is a good measure of TTO oxidative degradation, but oxidation processes also lead to the formation of endoperoxide Asc (de Groot and Schmidt 2016). Asc is classified as a moderate-strong sensitizer by the local lymph node assay with an $\mathrm{EC}_{3}$ value of 1.8 (Rudbäck et al. 2012). Also, we studied the elicitation potential of Asc in individuals with eczema and suspected fragrance allergy after topical exposure (Christoffers et al. 2013; 2014). The finding that every positive reaction to oxidized-TTO was accompanied by a positive reaction to Asc supported the hypothesis that Asc might be a contact allergen in oxidized-TTO. Furthermore, we studied (Krutz at al. 2015) the capacity of Asc to react with proteins and evaluated its potential to mature monocyte-derived dendritic cell (DC), two key events of chemical-induced sensitization (OECD, 2012). Some reactivity toward cysteine- but not lysinecontaining peptides was observed in the direct peptide reactivity assay (DPRA), the regulatory agencies approved in chemico method to assess the sensitizing potential of chemicals. Treatment of human monocyte-derived DC with Asc supported full DC maturation and induced significant upregulation of co-stimulatory CD86, CD80, CD40 molecules and the adhesion molecule CD54 in a time-dependent manner.

As for sensitizing allylic hydroperoxides derived from autoxidation of terpenes (Kao et al. 2011; 2014), and from evidence for radical mechanisms as triggers for protein reactivity of endoperoxides 
(Tang et al. 2005), a radical mechanism could be proposed for the protein-binding or other steps of the sensitization process to Asc including activation of the innate immune system. In the DPRA, the depletion of the cysteine peptide was much higher when Asc was treated with iron as radical inducer, compared to Asc itself. This activated Asc showed furthermore increased potential for induction of the Nrf2 target gene heme oxygenase 1 and upregulation of CD86 and CD54 on THP-1 cells, an established DC surrogate (Krutz at al. 2015). Moreover, the high-throughput screening dansyl cysteamine method (HTS-DCYA) applied to Asc and activated Asc with iron (II) revealed the formation of electrophilic species via radical degradation as a potential pathway for the peptide reactivity of aged TTO (Chittiboyina et al. 2016). However, the link between radicals actually formed in the epidermis and their mechanism of action are far from being fully unraveled.

The aim of the present study was to broaden knowledge about the contribution of free radical intermediates derived from Asc to 2 key events in the process of sensitization. We approached this by assessing the reactivity profile towards amino acids prone to radical reactions, by identifying whether Asc derived free radicals are formed in a reconstructed human epidermis 3D model (RHE) which is believed to be closer to what may happen in vivo, and by examination of its properties to activate the immune system, namely dendritic cells (DCs) in their natural context of keratinocytes and in the RHE epidermal skin environment. 


\section{Materials and methods \\ Synthesis of ascaridole (Asc)}

Chemicals were purchased from Sigma-Aldrich (Saint Quentin Fallavier, France) and used as received. The reactions were followed by TLC $\left(0.25 \mathrm{~mm}\right.$ silica gel plates; $\left.60 \mathrm{~F}_{254}\right)$. After migration, the plates were inspected under UV light $(254 \mathrm{~nm})$ and sprayed with a solution containing phosphomolybdic acid $(5 \mathrm{~g})$, cerium (IV) sulfate $(2 \mathrm{~g})$ and sulfuric acid $(12 \mathrm{~mL})$ in water $(188 \mathrm{~mL})$. Column chromatography

purification was performed using silica 60 (Geduran, 40-63 $\mu \mathrm{m}$ ). ${ }^{1} \mathrm{H}$ and ${ }^{13} \mathrm{C}$ NMR spectra were recorded in a Bruker Avance spectrometer at 300 and $75 \mathrm{MHz}$, respectively. Chemical shifts $(\delta)$ are reported in ppm, indirectly referenced to TMS via the solvent signal $\left(\mathrm{CDCl}_{3}: \delta{ }^{1} \mathrm{H} 7.26 ; \delta{ }^{13} \mathrm{C} 77.16\right)$. Multiplicities are denoted as s (singlet), d (doublet), hept (heptuplet) and m (multiplet). The spectroscopic data agree with reported literature data (Chittiboyina et al. 2016).

A microemulsion was prepared by adding sodium molybdate ( $2.3 \mathrm{~g}$ in $12 \mathrm{~mL}$ of distilled water) dropwise into a suspension of sodium dodecyl sulfate $(19 \mathrm{~g})$ in butanol $(23 \mathrm{~mL})$ and dichloromethane $(133 \mathrm{~mL})$. The microemulsion became clear after $25 \mathrm{~min}$ of stirring. A solution of $\alpha$-terpinene ( $3.3 \mathrm{~g}$, $24.5 \mathrm{mmol}, 1$ equiv) in the microemulsion $(50 \mathrm{~g})$ was treated at room temperature with a first portion of hydrogen peroxide $(35 \% \mathrm{wt}$ in water, $1 \mathrm{~mL}$ ). The brick red mixture was stirred for $10 \mathrm{~min}$ until it became light yellow. Thirteen additional portions of hydrogen peroxide ( $35 \% \mathrm{wt}$ in water, $1 \mathrm{~mL}$ each) were successively added every $10 \mathrm{~min}$. A total of $14 \mathrm{~mL}$ of aqueous hydrogen peroxide (35\%) was used (160 mmol, 6.5 equiv). The light yellow mixture was stirred overnight at room temperature until it became completely clear. The solvent was removed under reduced pressure and the crude product obtained was dissolved in dichloromethane $(100 \mathrm{~mL})$. The suspension was stirred vigorously for 45 min and filtered. The filtrate was evaporated under reduced pressure and the recovered oil was diluted in ethyl acetate $(20 \mathrm{~mL})$, washed with water $(3 \times 100 \mathrm{~mL})$ and the aqueous layers were extracted with ethyl acetate $(3 \times 30 \mathrm{~mL})$. The organic layers were dried over $\mathrm{MgSO}_{4}$, filtered and evaporated under reduced pressure. Purification by column chromatography on silica gel (petroleum ether/EtOAc 9:1) furnished ascaridole as a yellow oil ( $1.82 \mathrm{~g}, 10.8 \mathrm{mmol}, 45 \%$ yield). $R_{f}=0.61$ (petroleum ether/EtOAc 9:1). ${ }^{1} \mathrm{H}$ NMR (300 MHz, $\left.\mathrm{CDCl}_{3}\right) \delta 0.99(\mathrm{~d}, J=7.0 \mathrm{~Hz}, 6 \mathrm{H}), 1.36(\mathrm{~s}, 3 \mathrm{H}), 1.50-1.52(\mathrm{~m}, 2 \mathrm{H}), 1.91$ (hept, $J=6.9 \mathrm{~Hz}, 1 \mathrm{H}), 1.99-2.05(\mathrm{~m}, 2 \mathrm{H}), 6.40(\mathrm{~d}, J=8.5 \mathrm{~Hz}, 1 \mathrm{H}), 6.48(\mathrm{~d}, J=8.5 \mathrm{~Hz}, 1 \mathrm{H}) ;{ }^{13} \mathrm{C}$ $\operatorname{NMR}\left(75 \mathrm{MHz}, \mathrm{CDCl}_{3}\right) \delta 17.3,17.4,21.5,25.7,29.6,32.2,74.5,79.9,133.2,136.5$; CAS registry number [512-85-6]. 


\section{Reactivity with amino acids: general procedure}

Asc (100 mg, $0.59 \mathrm{mmol})$ was dissolved in deareated 1:1 (v/v) $\mathrm{H}_{2} \mathrm{O} / \mathrm{CH}_{3} \mathrm{CN}(15 \mathrm{~mL})$. The amino acids ( 2 equiv) were added together with a catalytic amount ( 0.1 equiv) of $\mathrm{FeSO}_{4}$ heptahydrate. The reaction mixtures were continuously stirred at room temperature and kept under argon atmosphere to minimize competing reactions with oxygen. Reactions were monitored by TLC $(0.25 \mathrm{~mm}$ silica gel plates; $\left.60 \mathrm{~F}_{254}\right)$. After migration, TLC plates were inspected under UV light $(254 \mathrm{~nm})$ then sprayed with the previously described phosphomolybdic acid solution followed by heating. Reactions were stopped after 7 days if Asc was still present in the reaction mixtures and the reactions did not evolve after that time. The mixtures were filtered on Celite (Celite 545) in order to remove iron salts and the filtrate solvent was removed in vacuo. Crude products were analyzed by LC-ESI-MS associated with ESI-MS/MS. LC-ESI-MS/MS analyses were performed using an ion trap mass Agilent QToF spectrometer connected to an Agilent 1200 HPLC system. The samples were subjected to reverse phase chromatography on a Zorbax SB-C18 column $(50 \mathrm{~mm} \times 2.1 \mathrm{~mm}, 1.8 \mu \mathrm{m}$ particle size $)$ at a flow rate of $0.5 \mathrm{~mL} / \mathrm{min}$. They were eluted from the column using a mobile phase A $(0.05 \%$ formic acid in acetonitrile $)$ and a mobile phase $\mathrm{B}\left(0.05 \%\right.$ formic acid in $\left.\mathrm{H}_{2} \mathrm{O}\right)$ with the following gradient: started at $98 \% \mathrm{~B}$ and decreased to $0 \% \mathrm{~B}$ after $8 \mathrm{~min}$, kept at $0 \% \mathrm{~B}$ during $12.5 \mathrm{~min}$, and increased again to $98 \%$

$\mathrm{B}$ after $12.5 \mathrm{~min}$, kept at $98 \% \mathrm{~B}$ during $13 \mathrm{~min}$ at the end. After passing through the diode array absorbance detector, the eluent was directed to the connected ion trap mass spectrometer with a standard electrospray source. The ionization method used was ESI in the positive ion mode (heated capillary temperature $340^{\circ} \mathrm{C}$, gas flow $8 \mathrm{~L} / \mathrm{min}$, nebulizer gas $30 \mathrm{psi}$ ). Full scan mass spectra were acquired in the profile mode scanning $\mathrm{m} / \mathrm{z} 50$ to 1000 . For the ESI-MS/MS studies, the mass spectrometer was equipped with the ESI source used for ESI-MS studies described above and with the same source parameter settings. The ionization mode was ESI in the positive ion mode. The isolation width was $4 \mathrm{~m} / \mathrm{z}$. Data were processed using Agilent MassHunter Qualitative Analysis software. Only molecular ions detected by LC-ESI-MS having an $\mathrm{m} / \mathrm{z}$ value in accordance with potential reactivity were considered as molecular species provided that they were relatively abundant. Even if unlikely, the eventuality of these ions being fragments of other molecular species cannot be excluded.

\section{EPR studies}

EPR spectra were recorded on an EPR X-band spectrometer (ESP300E, Bruker Biospin GmbH, Germany) equipped with a high sensitivity resonator (4119HS-W1, Bruker Biospin GmbH, Germany). The $g$ calibration was performed using Bruker standard (strong pitch) with known isotropic $g$ factor of 2.0028. The principal experimental parameters values were: microwave power of circa $5 \mathrm{~mW}$, 
modulation amplitude $1 \mathrm{G}$, and conversion time of circa $160 \mathrm{~ms}$ with 1024 points per spectrum resulting in a sweep time of circa $3 \mathrm{~min}$ per scan. Several spectra were accumulated to ensure a good signal-to-noise ratio $(\mathrm{S} / \mathrm{N})$. Spectra were recorded at room temperature $(295 \mathrm{~K} \pm 1 \mathrm{~K})$. All experimental EPR spectra were analyzed by means of computer simulation using labmade scripts based on Easyspin toolbox under Matlab (Mathworks) environment (Stoll and Schweiger 2006). Spin-trap 5-diethoxyphosphoryl-5-methyl-1-pyrroline $N$-oxide (DEPMPO) was synthesized as reported in the literature (Barbati et al. 1997).

For preliminary studies in solution, HEPES buffer $(10 \mathrm{mM}, \mathrm{pH} 6.8)$ was prepared with $1.19 \mathrm{~g}$ HEPES in $400 \mathrm{~mL}$ deionized water, $4 \mathrm{~g} \mathrm{NaCl}$ and $0.1 \mathrm{~g} \mathrm{KCl}$. Deionized water was added to a final volume of $500 \mathrm{~mL}$. Stock solutions were prepared for Asc $\left(10 \mathrm{mM}\right.$, HEPES/CH $\left.3 \mathrm{CN}_{9} / 1 \mathrm{v} / \mathrm{v}\right)$, DEPMPO (100 mM in HEPES) and $\mathrm{FeSO}_{4} .7 \mathrm{H}_{2} \mathrm{O}$ (10 mM in HEPES). $25 \mu \mathrm{L}$ of spin-trap solution were mixed with $\mathrm{FeSO}_{4} .7 \mathrm{H}_{2} \mathrm{O}$ (i. e. $0.5 \mu \mathrm{L}$ for a final concentration in the reaction mixture of $0.1 \mathrm{mM}$ ), $5 \mu \mathrm{L}$ Asc solution added and the final volume completed to $50 \mu \mathrm{L}$. This way, final concentrations in the reaction mixture were $50 \mathrm{mM}$ DEPMPO, $1 \mathrm{mM} \mathrm{Asc}$ and $0.1 \mathrm{mM}$ Fe(II). The reaction mixture was subjected to stirring, introduced into a glass capillary tube (Hirschamnn, $20 \mu \mathrm{L}$ ) sealed on both ends and EPR spectra registered.

EpiSkin $^{\mathrm{TM}}$ (Lyon, France) is an ex vivo reconstructed human epidermis (RHE) from normal human keratinocytes cultured for 13 days on a collagen matrix at the air-liquid interface. The small $0.38 \mathrm{~cm}^{2}$ format was chosen for these studies. Immediately after arrival in the laboratory, the RHE was removed from the agarose-nutrient solution in the shipping multiwell plate under a sterile airflow. It was immediately placed in a plate in which each well was previously filled with $2 \mathrm{~mL}$ EpiSkin $^{\mathrm{TM}}$ maintenance or growth medium at room temperature. Samples were placed in the incubator at $37^{\circ} \mathrm{C}$, $5 \% \mathrm{CO}_{2}$ and saturated humidity for at least $24 \mathrm{~h}$ before incubation. Afterwards, the RHE were treated with DEPMPO in dimethylsulfoxide/HEPES 1:1 $(250 \mathrm{mM}, 20 \mu \mathrm{L})$ and incubated for $15 \min \left(37^{\circ} \mathrm{C}\right.$, $5 \% \mathrm{CO}_{2}$ ). After that time, treated RHE were placed in an EPR tissue cell equipped with a silica window (Willmad, \#ER162TC-Q) and Asc (100 mM, $50 \mathrm{mM}, 25 \mathrm{mM}, 10 \mathrm{mM}$ or $5 \mathrm{mM}$ in acetone, $20 \mu \mathrm{L}$ ) was topically applied to the epidermis taking care to ensure that the solution was only applied to the skin surface. It was necessary to act quickly as the tissue cultures dry out rapidly if not in contact with medium. EPR spectra were then recorded. The principal experimental parameters values were: microwave power $5 \mathrm{~mW}$, modulation amplitude $1 \mathrm{G}$, and resulting sweep time of ca. $328 \mathrm{~s}$ for a single scan. Up to 10 scans were accumulated to improve the signal-to-noise ratio. 


\section{Activation of THP-1 cells cocultured with HaCaT keratinocytes}

HaCaT cells were cultured in media (DMEM) supplemented with $10 \%$ fetal bovine serum (FBS), 2 $\mathrm{mM}$ L-glutamine and 1\% antibiotic/antimycotic solution. THP-1 monocytes were established as surrogate for monocyte-derived DC by us (Tietze and Blömeke 2008) and others (Bocchietto et al. 2007). THP-1 cells were cultured in RPMI 1640 containing 4 mM L-glutamine, 25 mM HEPES, 50 $\mu \mathrm{M} \beta$-mercaptoethanol, 10\% FBS and 1\% antibiotic/antimycotic solution as we described (Hennen et al. 2011; Hennen and Blömeke 2017). THP-1 cells $(8 \times 104$ in a 96-well plate $)$ were placed on top of confluent $\mathrm{HaCaT}$ keratinocytes and exposed to increasing concentrations of Asc $(7.8-1000 \mu \mathrm{M}, 0.2 \%$ DMSO) and to $20 \mu \mathrm{M}$ DNCB $(0.2 \%$ DMSO) for varying times $(0.5 \mathrm{~h}-48 \mathrm{~h})$. After the indicated time points, the exposure medium (containing the test compound) was replaced by fresh medium without chemicals and cells were further incubated for $24 \mathrm{~h}$ or $48 \mathrm{~h}$ at $37{ }^{\circ} \mathrm{C}, 5 \% \mathrm{CO}_{2}$ in a humidified atmosphere. The number of experiments performed for each time point were: $n=1-3$ for $0.5 h ; n=3-5$ for $1 \mathrm{~h} ; \mathrm{n}=4-5$ for $2.5 \mathrm{~h}$ and $24 \mathrm{~h} ; \mathrm{n}=2-3$ for $4 \mathrm{~h}$ and $\mathrm{n}=3$ for $48 \mathrm{~h}$.

\section{Activation of THP-1 cells cocultured with RHE}

Here reconstructed human epidermis SkinEthic ${ }^{\mathrm{TM}}$ (Lyon, France) model of $0.5 \mathrm{~cm}^{2}$ format mounted on a semipermeable membrane was used. This design allowed us to place the THP-1 cells underneath the RHE (the details are described by Schellenberger et al. in revision). After removal of the agarosenutrient solution each of the inserts was placed overnight in a 6-well plate with EpiSkin maintenance medium at $37{ }^{\circ} \mathrm{C}, 5 \% \mathrm{CO}_{2}$. THP-1 cells were seeded in the basolateral compartment underneath the RHE model, in a 12-well culture plate containing $500 \mu \mathrm{L}$ of THP-1 culture medium without $\beta$ mercaptoethanol. Increasing concentrations of Asc 10 mM, 60 mM, $100 \mathrm{mM}$ and $200 \mathrm{mM}$, dissolved in acetone-olive oil (AOO, 4:1) were applied on top of the skin models (volume of $6 \mu \mathrm{L}$ ) and incubated for $24 \mathrm{~h}$ at $37^{\circ} \mathrm{C}$ and $5 \% \mathrm{CO}_{2}$ in a humidified incubator.

\section{Cell surface expression of CD86 and CD54 on cocultured THP-1 cells}

THP-1 cells were harvested and cell surface expression (mean fluorescence intensities, MFI) of CD86 and CD54 was analyzed on THP-1 cells (PI or DAPI negative) via flow cytometry. Briefly, THP-1 cells were stained with fluorescein isothiocyanate (FITC)-labeled anti-CD86 (clone 2331 [FUN-1]), APC-labeled anti-CD54 (clone HA58) monoclonal antibodies (all mouse IgG1, obtained from BD Pharmingen, Heidelberg, Germany) or corresponding isotype controls. Then, the chemical-induced MFIs were calculated or the difference in cell surface levels of CD86 or CD54 ( $\triangle \mathrm{MFI})$ was calculated for each sample. 


\section{Results}

\section{Reactivity with amino acids prone to radical reactions}

Reactivity towards cysteine, tryptophan and tyrosine ( $N$-acetylated, ester form) was studied. Cysteine is probably the most labile residue involved in radical reactions induced by peroxides. A well-known example is the $\mathrm{Fe}(\mathrm{II}) / \mathrm{Fe}$ (III) induced radical mechanism proposed for the interaction of cysteine with antimalarial endoperoxide artemisinin involving C-centered radicals (Wang et al. 2001; O'Neill et al. 2010). Tryptophan, redox-active, plays a key role in several biological multistep electron transfer processes. Oxidation results in formation of Trp-derived indolyl radicals which can undergo further reactions, i.e. with $\mathrm{O}_{2}$ giving peroxyl radicals, dimerization, hydrogen abstraction from compounds with weak $\mathrm{H}$-bonds or $\beta$-scission reactions producing fragmentation of side-chains or backbones from proteins (Carroll et al. 2018). Tyrosine modification by biological oxidants depends essentially on the formation of Tyr-radicals located in carbon-centered positions of the benzene ring, as for the wellknown nitration of protein tyrosine residues occurring through free radical-mediated pathways (Bartesaghi and Radi, 2018).

Asc and the amino acids (2 equiv) in a deareated 1:1 (v/v) $\mathrm{H}_{2} \mathrm{O} / \mathrm{CH}_{3} \mathrm{CN}$ mixture were treated with a catalytic amount of $\mathrm{FeSO}_{4}$ (radical initiator) at room temperature. TLC indicated that Asc was not completely consumed even after 7 days. Reactions were then stopped, the solvent removed under reduced pressure and the crude products analysed by LC-ESI-MS/MS. Asc only reacted with $N$-AcCys-OMe to afford 1-3 (Fig.1), whereas oxidation/degradation products of $N$-Ac-Trp-OEt (Fig. S1) and dimerization of $\mathrm{N}$-Ac-Tyr-OEt (Fig. S2) were observed. In the case of $\mathrm{N}$-Ac-Cys-OMe the reactivity was already noticed in the blank reactions conducted without $\mathrm{Fe}(\mathrm{II})$ albeit this was very limited. LCMS of the reaction Asc/ $N$-Ac-Cys-OMe/ $/ \mathrm{FeSO}_{4}$ crude product showed one major peak with associated $\mathrm{m} / z$ of 352 corresponding to the cysteine disulfide dimer, and two other peaks with $\mathrm{m} / z 303$ and 345 . MS fragmentation of 303 displayed a fragment ion at $m / z 178$ due to the loss of $N$-Ac-Cys-OMe. Also, the $303 \mathrm{~m} / \mathrm{z}$ value indicated loss of the Asc isopropyl group. Mechanistically, activation of the endoperoxide with $\mathrm{Fe}(\mathrm{II})$ facilitates the cleavage of the O-O bond to form oxygenated-radicals. Then, formation of $\alpha, \beta$-unsaturated ketone 4 is possible through fragmentation and loss of a stable isopropyl radical. 4 can further undergo Michael addition with the nucleophilic thiol group of cysteine, as described previously for other thiol reagents (Chittiboyina et al. 2016). Peak at $\mathrm{m} / \mathrm{z} 345$ could match with both, $\mathbf{2}$ and 3. Isoascaridole (IsoAsc, Fig. 1c) is a known byproduct obtained after decomposition of Asc (Satyal et al. 2012). Further nucleophilic thiol ring opening of the oxirane moieties should be at the origin of $\mathbf{2} / \mathbf{3}$. Due to the inherent electrophilic feature of ketone 4 and IsoAsc we studied the 
reactivity of activated Asc against $N$-Ac-Lys-OMe and this in order to check its observed non-reactivity toward DPRA lysine-containing peptide (Krutz at al. 2015) confirming the result.

The fact that only oxidation/degradation/dimerization derivatives from $N$-Ac-Trp-OEt and $N$-AcTyr-OEt were observed indicated the oxidative strength of the media, inducing the production of a number of reactive radical species involved in a permanent game of redox reactions able to chemically modify certain amino acids themselves as previously observed in the case of some sensitizing allylic hydroperoxides (Kao et al. 2014).

\section{EPR studies}

Electron paramagnetic resonance spectroscopy (EPR)-spin trapping (ST) is the most efficient technique for the identification of transient radicals in chemical and biological systems. Basically, radical intermediates that are too short-lived or of too low concentration to be directly detected react with a spin-trap to form more persistent radicals (spin-adducts) observed by EPR with a signature depending on the trapped transient reactive species (Lauricella and Tuccio 2014). We recently developed a new EPR-ST methodology with the potential to investigate in situ the formation and behaviour of free radicals derived from xenobiotics in a reconstructed human epidermis 3D model (RHE) (Kuresepi et al. 2018). RHE consist of a normal multi-layered keratinocytes culture, the major cell type in the epidermis playing a key role in skin inflammatory reactions. Using this approach, several O- and Ccentred radicals were identified in this complex environment using cumene hydroperoxide as proof of concept. Thus, to study the basic triggers for activation of Asc in the skin, we employed here this EPRST methodology applied to RHE EpiSkin ${ }^{\mathrm{TM}}$.

Studies in solution were firstly carried out to set up the optimal experimental conditions while providing a good $\mathrm{S} / \mathrm{N}$ and keeping the Asc concentrations as low as possible, suitable with physiological conditions. DEPMPO was chosen as spin-trap, based on (i) our previous studies (Kuresepi et al. 2018) (ii) its ability to clearly distinguish O- and C-centred radicals (Stolze et al. 2000) (iii) the high persistency of its superoxide and alkyl-peroxyl radicals spin-adducts (Frejaville et al. 1995). Spin-adducts are formed by the addition of transient short-lived radicals to the $\alpha-C$ of the nitronyl group of the spin-trap. Radical initiation was triggered by catalytic Fe(II)-induced endoperoxide cleavage. DEPMPO in large excess $(50 \mathrm{mM})$ with respect to Asc $(1 \mathrm{mM})$ was mixed with $\mathrm{Fe}(\mathrm{II})(0.1 \mathrm{mM})$ and the mixture subjected to conventional field-swept continuous wave-EPR spectroscopy (cw-EPR) in a sealed glass capillary. HEPES was preferred to phosphate buffer to avoid the formation of insoluble Fe(III) through the autoxidation of Fe(II) catalysed by phosphate and thus decreasing the Fe(II) content available (Pazos et al. 2006; Kuresepi et al. 2018). EPR spectra recorded 
after activation of Asc with Fe(II) in solution are shown in Fig.2. The spectrum shown in Fig. 2d was assigned to a mixture of spin-adducts formed by trapping two C-centred radicals with characteristic $g$ factor and hyperfine coupling constants ( $h f c c s$; Gauss) values of $g=2.0056, a_{\mathrm{N}}=14.7, a_{\mathrm{H}}=21.5, a_{\mathrm{P}}=47.2$ and $g=2.0057, a_{\mathrm{N}}=15.0, a_{\mathrm{H}}=25.8, a_{\mathrm{P}}=47.7$, respectively. The use of higher $\mathrm{Fe}(\mathrm{II})$ and Asc concentrations did not provide significant additional information (Fig. S3).

In a second phase, experiments were carried out in RHE based on a topical application procedure to get closer to real life sensitization. EpiSkin ${ }^{\mathrm{TM}}$ RHE is a very good replicate of human epidermis architecture. It is used for irritation and penetration tests of cosmetic and chemical compounds as replacement of in vivo testing. In OECD guidelines on in vitro skin irritation assessment by using such RHE system it is specified that test chemicals must be applied topically to the RHE model (OECD 2015). In order to carry out these experiments, the skin samples were initially loaded with DEPMPO to ensure that it is present at the site of radical generation before application of Asc (Timmins and Davies 1993). To cause this loading, RHE were pre-treated with DEPMPO in 50\% DMSO, this way facilitating penetration of the spin-trap through the stratum corneum. When RHE pre-treated with

DEPMPO were exposed topically to different concentrations of Asc in acetone, EPR spectra of DEPMPO radical trapping was observed from a $10 \mathrm{mM}$ concentration, with the best signal-to-noise ratio obtained at $50 \mathrm{mM}$ (Fig. 3d, Fig S4). As for the investigations in solution, the fingerprints of two $\mathrm{C}$-centred radical DEPMPO spin-adducts were detected. These spin-adducts could be assigned to Cradical trapping based on their $h f c c s\left(a_{\mathrm{N}}=14.8 \mathrm{G}, a_{\mathrm{H}}=21.6 \mathrm{G}, a_{\mathrm{P}}=47.4 \mathrm{G}, g=2.0049\right.$ and $a_{\mathrm{N}}=14.8 \mathrm{G}$, $\left.a_{\mathrm{H}}=22.8 \mathrm{G}, a_{\mathrm{P}}=50.5 \mathrm{G}, g=2.0048\right)$. When comparing these $h f c c s$ values with those obtained in the EPRST solution studies, some differences are however observed, especially for one of the radicals trapped. This could be partially explained because the environment of the spin-adducts is necessarily different in solution compared to that of a complex heterogeneous tissue such as the epidermis. The magnitude of the $h f c c s$ indicating the extent of delocalization of the unpaired electron over the molecule, this may be affected by changes in the matrix environment and polarity. Finally, the incubation in the RHE of the sole Asc or DEPMPO (Figs. 3a, 3b) gave no signal, indicating that the C-radicals originate rather from Asc than from RHE biomolecules. Worthy of note, after penetrating the RHE, Asc radical initiation should have been induced by RHE itself as no Fe(II) was added in RHE experiments.

\section{Activation of THP-1 cells cocultured with HaCaT keratinocytes}

Since cross-talk between structural cells like keratinocytes and immune cells is likely to be critical in determining the outcome of sensitizer exposure, our aim was to co-expose keratinocytes and immune cells and evaluate the impact of this environment on the activation of dendritic cells. For this purpose 
we evaluated the activation of THP-1 cells cocultured with HaCaT keratinocytes and exposed to several concentrations of Asc for varying time points without adding iron as a radical starter $(\mathrm{t}=0.5-48$ h). A low (non-toxic), medium and high (toxic) concentration was selected in order to understand how cell death has impact on the dendritic cell phenotype. Results are summarized in Fig.4. Treatment of cells with the positive control (20 $\mu \mathrm{M}$ DNCB) promoted upregulation of CD86 and CD54 already after $1 \mathrm{~h}$. For Asc, low concentrations $(62.5 \mu \mathrm{M}$ and lower) promoted CD54 upregulation after exposure for $24 \mathrm{~h}$ and $48 \mathrm{~h}$. This pattern could not be overcome by using higher concentrations (up to $1000 \mu \mathrm{M}$ ) for shorter exposure times. These data are in line with the common believe that it is the concentration of reactive intermediates and/or protein antigens and not the parent compound, which determines whether cells of the innate immune system are activated.

\section{Activation of THP-1 cells cocultured with RHE}

The chemical and biological microenvironment can have an intense effect on dendritic cell phenotype and function and on the nature of the adaptive immune response that follows antigen presentation to $\mathrm{T}$ cells. Therefore, we aimed to evaluate the microenvironment provided by a RHE model and placed the THP-1 cells underneath the RHE. This allows studying dendritic cell activation after topical exposure of keratinocytes thereby simulating more realistic skin conditions (Christoffers, 2014). Based on the EPR results, we used concentrations of Asc $(10-80 \mathrm{mM})$ that all generate radicals, thereby allowing us to monitor their effects on keratinocyte/dendritic cell signaling. The results are depicted in Fig.5. With respect to concentration needed, we observed no clear upregulation of CD54 and CD86 after application of up to $30 \mathrm{mM}$ Asc, while clear upregulation was observed after $24 \mathrm{~h}$ and application of 60 $\mathrm{mM}$. In line, short exposure time $(0.5 \mathrm{~h})$ with $60 \mathrm{mM}$ and for which we detected already radicals, did not result in THP-1 activation (data not shown). Important, we found no impact of the tested concentrations on THP-1 cell variability, thus the data generated provide specific information on the signaling molecules released from keratinocytes and how keratinocyte-derived signals affect the activation of the innate immune system. These data suggest that possibly not the radicals but likely the rearranged products that build up in time, may be responsible for the activation of the cells, although this needs clearly further investigations. 


\section{Discussion}

Asc has been this last decade object of multiple studies to elucidate its mechanism(s) of action, not only in the context of ACD to tea tree oil, but also as the anthelmintic principle of Chenopodium oil. It was used for centuries to treat parasitic diseases but it is irritant to the gastrointestinal tract and genotoxic (Monzote et al. 2009), or in the treatment of cutaneous leishmaniasis for example (Geroldinger et al. 2017). In these studies, evidence for Asc C-centered radical intermediates arising from $\mathrm{Fe}(\mathrm{II})$-induced degradation was obtained by using EPR-ST. On the basis of artemisinin's mode of action, important antimalarial drugs, cleavage of the peroxide bond via reduction by Fe(II) is the accepted pathway to initially form highly reactive alkoxyl radicals that further rearrange giving long half-life reactive $\mathrm{C}$ centered radicals. Although this mechanism might be of relevance for the skin sensitizing action of Asc, to our knowledge so far, there is no publication demonstrating directly the activation of this endoperoxide in the skin to C-centered radicals, as well as the relationship with associated immune responses in skin cells and keratinocyte/dendritic cell signaling. In the work reported herein, the use of a recently developed EPR-ST methodology to elucidate whether radicals can be formed from xenobiotics in the EpiSkin ${ }^{\mathrm{TM}}$ 3D RHE model showed for the first time that C-radicals derived from Asc are formed in this epidermal-like skin environment. As showed previously in EPR studies by irradiating TTO (436 nm) in presence of Fe(II) and flavin mononucleotide, combined with HPLC-EPR analysis, two C-radicals could be formed from Asc, the isopropyl (1-methyl ethyl) and the methyl radical (Mori and Iwahashi 2013). In our studies we also detected in RHE two DEPMPO spin-adducts with $h f c c s$ characteristic of C-radicals trapped. DEPMPO is known to produce stereo-specific isomers when trapping superoxide or alkylperoxyl radicals on both planar sides of the spin-trap leading to two slightly different and superimposed EPR fingerprints (Clément et al. 2003). However, this has not been well defined in the case of trapped C-radicals. If we could thus hypothesize that the two C-radicals trapped were of different nature, the trapping of a single $\mathrm{C}$-radical species on both sides of DEMPO molecule giving such mixed EPR signature couldn't be excluded. No spin-adduct was observed for control experiments performed in absence of Asc, suggesting that DEPMPO trapped radicals most probably originated from Asc rather than through biomolecules present in RHE. Last but not least, no Fe(II) was used for radical initiation when using RHE to mimic real life skin allergy situation. One can hypothesize that reaction of organic peroxides in the skin in the presence of one-electron donor agents (e.g. amino and thiol groups present in amino acids, metal complexes, enzymes) may start the electron transfer processes under radical oxidation conditions and further skin proteins haptenation (Fujimoto and Masuda 2012). 
To be a sensitizer, Asc needs to covalently bind to skin proteins to form the antigenic entity for the interaction of dendritic cells with the $\mathrm{T}$ cell receptor of naïve $\mathrm{T}$ cells. In addition, sufficient activation and maturation of dendritic cells is needed to provide co-stimulation and thereby influencing the strength of $\mathrm{T}$ cell receptor signalling and consequently the nature of the adaptive immune response (Steinman 2007). Even if we have proved that C-radicals are formed in the skin, this does not corroborate that they are the reactive intermediates towards skin proteins and maturation of dendritic cells. Radical degradation of Asc is known to yield electrophilic reactive species such as IsoAsc and $\alpha, \beta$-unsaturated ketone 4 that could react with nucleophilic residues present on skin proteins. Indeed, we have shown in this work that both can react with the thiol group of $N$-Ac-Cys-OMe through a nucleophile-electrophile mechanism. We observed $\mathbf{1}$ derived from reaction of $\mathbf{4}$ formed after loss of stable isopropyl radical, in agreement with the observation of C-radicals of the isopropyl kind in RHE EPR-ST studies. However, we did not observe reactivity derived from reaction of intermediates formed after loss of methyl radical. In parallel, IsoAsc electrophilic epoxide chemical functions could also react with thiol groups and form antigenic structures. We have thus the impression that radicals formed in RHE are not themselves the reactive species towards amino acids, but the electrophilic intermediates derived from radical degradation of Asc. Formation of electrophilic species via radical degradation in the skin is thus also one possible pathway to trigger sensitization to Asc. Further, both danger signals from formed C-radicals and chemical-induced and oxidative stress signalling (ROS) may jointly have promoted activation of keratinocytes and dendritic cells following Asc exposure. For Asc these aspects still need to be further elucidated.

\section{Conclusion}

In this study we have demonstrated that Asc is activated in the skin resulting in the formation of high reactive alkoxyl radicals that further rearrange into $\mathrm{C}$-radicals, and that under these conditions dendritic cell activation is promoted. However, we could not directly link C-radicals as being reactive intermediates towards skin proteins. The fact that time plays a crucial role in dendritic cell activation

after exposure to Asc leads us to hypothesize that this could be promoted as a combined effect of formation of electrophilic reactive species together with a depletion of keratinocytes scavenging properties. 


\section{Acknowledgements}

This work was part of the DEFCHEMSKALL Franco-German Collaborative International Research Project financially supported by the ANR (Agence Nationale de la Recherche; project no. ANR-15CE15-0023-01) and the DFG (Deutsche Forschungsgemeinschaft; project no. DFG, BL340/6-1). The Reseau NAtional de Rpe interDisciplinaire (RENARD, Fédération IR-RPE CNRS \#3443) is also acknowledged.

\section{Compliance with ethical standards}

The manuscript does not contain clinical studies or patient data.

\section{Conflict of interest}

The authors declare that they have no conflicts of interest. 


\section{References}

Barbati S, Clément JL, Olive G, Roubaud V, Tuccio B, Tordo P (1997) In Minisci F. Ed. Free Radicals in Biology and Environment. Kluwer Academic Publishers, Dordrecht, The Netherlands, pp. 3947.

Bartesaghi S, Radi R (2018) Fundamentals on the biochemistry of peroxynitrite and protein tyrosine nitration. Redox Biol 14: 618-625. doi: 10.1016/j.redox.2017.09.009.

Bocchietto E, Paolucci C, Breda D, Sabbioni E, Burastero SE (2007) Human monocytoid THP-1 cell line versus monocyte-derived human immature dendritic cells as in vitro models for predicting the sensitizing potential of chemicals. Int $\mathrm{J}$ Immunopathol Pharmacol 20: 259-65. doi:10.1177/039463200702000206.

Carroll L, Pattison DI, Davies JB, Anderson RF, Lopez-Alarcon C, Davies MJ (2018) Superoxide radicals react with peptide-derived tryptophan radicals with very high rate constants to give hydroperoxydes as major products. Free Radic Biol Med 118: 126-136. doi: 10.1016/j.freeradbiomed.2018.02.033.

Chittiboyina AG, Avonto C, Khan IA (2016) What happens after activation of ascaridole? Reactive compounds and their implications for skin sensitization. Chem Res Toxicol 29: 1488-1492. doi: 10.1021/acs.chemrestox.6b00157.

Christoffers WA, Blömeke B, Coenraads P-J, Schuttelar M-LA (2013) Co-sensitization to ascaridole and tea tree oil. Contact Dermatitis 69: 181-191. doi: 10.1111/cod.12086.

Christoffers WA, Blömeke B, Coenraads P-J, Schuttelar M-LA (2014) The optimal patch test concentration for ascaridole as a sensitizing component of tea tree oil. Contact Dermatitis 71: 129137. doi: 10.1111/cod.12199.

Clément JL, Finet JP, Fréjaville C, Tordo P (2003) Deuterated analogues of the free radical trap DEPMPO: synthesis and EPR studies. Org Biomol Chem 1: 1591-1597. doi: 10.1039/B300870C.

de Groot AC, Schmidt E (2016) Tea tree oil: contact allergy and chemical composition. Contact Dermatitis 75: 129-143. doi: 10.1111/cod.12591.

Frejaville C, Karoui H, Tuccio B, Le Moigne F, Culcasi M, Pietri S, Lauricella R, Tordo P (1995) 5(Diethoxyphosphoryl)-5-methyl-1-pyrroline $N$-oxide: a new efficient phosphorylated nitrone for the in vitro spin trapping of oxygen-centered radicals. J Med Chem 38: 258-265. doi: $10.1021 / \mathrm{jm} 00002 \mathrm{a} 007$. 
Fujimoto A, Masuda T (2012) Chemical interaction between polyphenols and a cysteinyl thiol under radical oxidation controls. J Agric Food Chem 60: 5142-5151. doi: 0.1021/jf3008822.

Geroldinger G, Tonner M, Hettegger H, Bacher M, Monzote L, Walter M, Staniek K, Rosenau T, Gille L (2017) Mechanism of ascaridole activation in Leishmania. Biochem Pharmacol 132: 48-62. doi: 10.1016/j.bcp.2017.02.023.

Hausen BM, Reichling J, Harkenthal M (1999) Degradation products of monoterpenes are the sensitizing agents in tea tree oil. Am J Contact Dermatitis 10: 68-77. doi: 10.1016/S1046199X(99)90002-7.

Hennen J, Aeby P, Goebel C, et al. (2011) Cross talk between keratinocytes and dendritic cells: impact on the prediction of sensitization. Toxicol Sci 123: 501-510. doi:10.1093/toxsci/kfr174.

Hennen J, Bloemeke B (2017) COCAT-advanced in vitro assessment of skin sensitization potency of chemicals using THP-1 cells in coculture with HaCaT keratinocytes. In: Naunyn-Schmiedebergs Archives of Pharmacology. Vol 390. Springer, 233 Spring St, New York, NY 10013 USA, pp. S87-S87.

Kao D, Chaintreau A, Lepoittevin J-P, Giménez-Arnau E (2011) Synthesis of allylic hydroperoxides and EPR spin-trapping studies on the formation of radicals in iron systems as potential initiators of the sensitizing pathway. J Org Chem 76: 6188-6200. doi: 10.1021/jo200948x.

Kao D, Chaintreau A, Lepoittevin J-P, Giménez-Arnau E (2014) Mechanistic studies on the reactivity of sensitizing allylic hydroperoxides: investigation of the covalent modification of amino acids by carbon-radical intermediates. Toxicol Res 3, 278-289. doi: 10.1039/C3TX50109D.

Krutz NL, Hennen J, Korb C, Schellenberger MT, Gerberick GF, Blömeke B (2015) Activation of the endoperoxide ascaridole modulates its sensitizing capacity. Toxicol Sci 147: 515-523. doi: 10.1093/toxsci/kfv148.

Kuresepi S, Vileno B, Turek P, Lepoittevin J-P, Giménez-Arnau E (2018) Potential of EPR spintrapping to investigate in situ free radicals generation from skin allergens in reconstructed human epidermis: cumene hydroperoxyde as proof of concept. Free Radic Res 52: 171-179. doi: 10.1080/10715762.2017.1420906.

Lauricella R, Tuccio B (2014) Détection et caractérisation de radicaux libres après piégeage de spins. In: Bertrand P (ed) La Spectroscopie de Résonance Paramagnétique Électronique-Applications. Collection Grenoble Sciences, edp Sciences, pp. 49-78.

Lepoittevin JP (2011) Molecular aspects in allergic and irritant contact dermatitis. In: Johansen JD, Frosch PJ, Lepoittevin JP (eds) Contact Dermatitis $5^{\text {th }}$ Ed. Springer-Verlag, Berlin, Heidelberg, pp. 91-110. 
Monzote L, Stamberg W, Staniek K, Gille L (2009) Toxic effects of carvacrol, caryophyllene oxide, and ascaridole from essential oil of Chenopodium ambrosioides on mithocondria. Toxicol Appl Pharmacol 240: 337-347. doi: 10.1016/j.taap.2009.08.001.

Mori HM, Iwahashi H (2013) Detection and identification of 1-methylethyl and methyl radicals generated by irradiating tea tree (Melaleuca alternifolia) oil with visible light (436 $\mathrm{nm})$ in the presence of flavin mononucleotide and ferrous ion. Free Radic Res 47: 657-663. doi: $10.3109 / 10715762.2013 .812785$.

OECD (2012) The adverse outcome pathway for skin sensitization initiated by covalent binding to proteins. Part 1: Scientific evidence. OECD Series on Testing and Assessment No. 168 (ENV/JM/MONO(2012)10/PART1). OECD Publishing, Paris. doi: 10.1787/9789264221444-en.

OECD testing guideline 439 (2015) In vitro skin irritation: RHE test method. doi: 10.1787/9789264242845-en.

O'Neill PM, Barton VE, Ward SA (2010) The molecular mechanism of action of artemisinin-the debate continues. Molecules 15: 1705-1721. doi: 10.3390/molecules15031705.

Pazos M, Andersen ML, Skibsted LH (2006) Amino acid and protein scavenging of radicals generated by iron/hydroperoxide system: an electron spin resonance spin trapping study. J Agric Food Chem 54: 10215-10221. doi : 10.1021/jf062134n.

Pesonen M, Jolanki R, Larese Filon F, Wilkinson M, Kręcisz B, Kieć-Swierczyńska M et al (2015) Patch test results of the European baseline series among patients with occupational contact dermatitis across Europe-analyses of the European Surveillance System on Contact Allergy network, 2002-2010. Contact Dermatitis 72: 154-163. doi: 10.1111/cod.12333.

Rudbäck J, Andresen Bergström M, Börje A, Nilsson U, Karlberg A-T (2012) $\alpha$-Terpinene, an antioxidant in tea tree oil, autoxidizes rapidly to skin allergens on air exposure. Chem Res Toxicol 25: 713-721. doi: 10.1021/tx200486f.

Satyal P, Paudel P, Kafme A, Pokharel SK, Lamichhane B, Dosoky NS et al (2012) Bioactivities of volatile components from Nepalese Artemisia species. Nat Prod Commun 12: 1651-1658.

Scientific Committee on Consumer Products (SCCP) (2008) Opinion on Tea Tree Oil. Adopted by the SCCP during the $18^{\text {th }}$ plenary meeting of 16 December 2008. SCCP Report 1155/08. Available at: https://ec.europa.eu/health/ph_risk/committees/04_sccp/docs/sccp_o_160.pdf.

Steinman RM (2007) Dendritic cells: understanding immunogenicity. Eur J Immunol 37 (Suppl 1): S53-60. doi:10.1002/eji.200737400.

Stoll S, Schweiger A (2006) EasySpin, a comprehensive software package for spectral simulation and analysis in EPR. J Magn Res 178: 42-55. doi:10.1016/j.jmr.2005.08.013. 
Stolz K, Udilova N, Nohl H (2000) Spin trapping of lipid radicals with DEPMPO-derived spin traps: detection of superoxide, alkyl and alkoxyl radicals in aqueous and lipid phase. Free Radic Biol Med 29: 1005-1014. doi: 10.1016/S0891-5849(00)00401-9.

Tang Y, Dong Y, Wang X, Sriraghavan K, Wood JK, Vennerstrom JL (2005) Dispiro-1,2,4-trioxane analogues of a prototype dispiro-1,2,4-trioxolane: mechanistic comparators for artemisinin in the context of reaction pathways with iron (II). J Org Chem 70: 5103-5110. doi: 10.1021/jo050385+.

Timmins GS, Davies MJ (1993) Free radical formation in murine skin treated with tumour promoting organic peroxides. Carcinogenesis 14: 1499-1503. doi: 10.1093/carcin/14.8.1499.

Tietze C, Blömeke B (2008) Sensitization assays: monocyte-derived dendritic cells versus a monocytic cell line (THP-1). J Toxicol Environ Health A 71: 965-968. doi:10.1080/15287390801989168.

Wang D-Y, Wu Y-L, Wu Y, Liang J, Li Y (2001) Further evidence for the participation of primary carbon-centered free radicals in the antimalarial action of the qinghaosu (artemisinin) series of compounds. J Chem Soc Perkin Trans 1: 605-609. doi: 10.1039/b008145k. 


\section{Figure Captions}

Fig.1 Reaction Asc/N-Ac-Cys-OMe/FeSO 4 studied by LC-ESI-MS/MS. (a) LC chromatogram of the reaction. (b) ESI-MS/MS of $\mathrm{m} / z 303$ at $t_{\mathrm{R}} 3.48 \mathrm{~min}$. (c) Mechanistic pathway suggested for the formation of 1-3.

Fig.2 Reaction Asc (1 mM)/DEPMPO (50 mM)/Fe (II) $(0.1 \mathrm{mM})$ in HEPES (10 mM, pH 6.8): (a) possible reaction paths for the formation of isopropyl and methyl carbon radicals; (b) control EPR spectrum with single DEPMPO; (c) control EPR spectrum with DEPMPO and Fe(II) (1 mM); (d) EPR spectrum of the reaction (circles DEPMPO-carbon R1, triangles DEPMPO-carbon R2); (e) computer simulation; (f-g) deconvolution of (e) with: (f) DEPMPO-carbon R1 spin-adduct $\left(a_{\mathrm{N}}(\mathrm{G})=14.7, a_{\mathrm{H}}(\mathrm{G})\right.$ $\left.=21.5, a_{\mathrm{P}}(\mathrm{G})=47.2, g=2.0056,83 \%\right)$ and $(\mathrm{g})$ DEPMPO-carbon R2 spin-adduct $\left(a_{\mathrm{N}}(\mathrm{G})=15.0, a_{\mathrm{H}}\right.$ $\left.(\mathrm{G})=25.8, a_{\mathrm{P}}(\mathrm{G})=47.7, g=2.0057,17 \%\right)$.

Fig.3 EPR spectra obtained in RHE after topical application of Asc: (a) RHE control experiment with single Asc in acetone; (b) RHE control experiment with single DEPMPO in vehicle; (c) RHE spectra after incubation of DEPMPO $\left(15 \mathrm{~min}, 37^{\circ} \mathrm{C}, 5 \% \mathrm{CO}_{2}\right)$ followed by Asc $(5 \mathrm{mM})$ addition; (d) RHE spectra after incubation of DEPMPO (15 min, $\left.37^{\circ} \mathrm{C}, 5 \% \mathrm{CO}_{2}\right)$ followed by Asc $(50 \mathrm{mM})$ addition. Labels identify each spin-adduct formed (circles DEPMPO-carbon R1, triangles DEPMPOcarbon R2); (e) computer simulation with DEPMPO-carbon R1 spin-adduct $\left(a_{\mathrm{N}}(\mathrm{G})=14.8, a_{\mathrm{H}}(\mathrm{G})=\right.$ 21.6, $\left.a_{\mathrm{P}}(\mathrm{G})=47.4, g=2.0049,83 \%\right)$ and $(\mathrm{g})$ DEPMPO-carbon R2 spin-adduct $\left(a_{\mathrm{N}}(\mathrm{G})=14.8, a_{\mathrm{H}}(\mathrm{G})\right.$ $\left.=22.8, a_{\mathrm{P}}(\mathrm{G})=50.5, g=2.0048,17 \%\right)$.

Fig.4 Impact of concentration and exposure time on CD86 and CD54 expression on cocultured THP-1 cells with HaCaT exposed to Asc and DNCB. THP-1 cells cocultured with HaCaT were exposed to increasing concentrations of Asc $(7.8-1000 \mu \mathrm{M})$ for increasing times $(\mathrm{t}=0.5-48 \mathrm{~h})$. DNCB $(20 \mu \mathrm{M})$ served as positive control. Cell surface expression of CD86 (squares), CD54 (triangles) on collected THP-1 cells (viability, grey dots) was analyzed by flow cytometry. Upregulation of CD86 and CD54 on the surface of THP-1 cells was calculated as difference in mean fluorescence intensities between chemical-treated and solvent-exposed cells and given in $\Delta$ MFI. Mean \pm SE, $n=5$, except $n=3$ $(\mathrm{t}=0.5 \mathrm{~h}, 4 \mathrm{~h}$ and $48 \mathrm{~h})$.

Fig.5 Impact of Asc concentration on CD86 and CD54 expression on cocultured THP-1 cells underneath RHE. RHE/THP-1 were treated with acetone-olive oil 4:1 (AOO) and Asc for $\mathrm{t}=24 \mathrm{~h}$ (mean $\pm \mathrm{SE}, \mathrm{n}=5)$ and $0.5 \mathrm{~h}(\mathrm{n}=1)$. CD86 (A and C) and CD54 (B and D) expression was analyzed on

viable THP-1 cells by flow cytometry. MFI, mean fluorescence intensity. $\S$ THP-1 reduction of viability higher than $50 \%$. 
Fig. 1
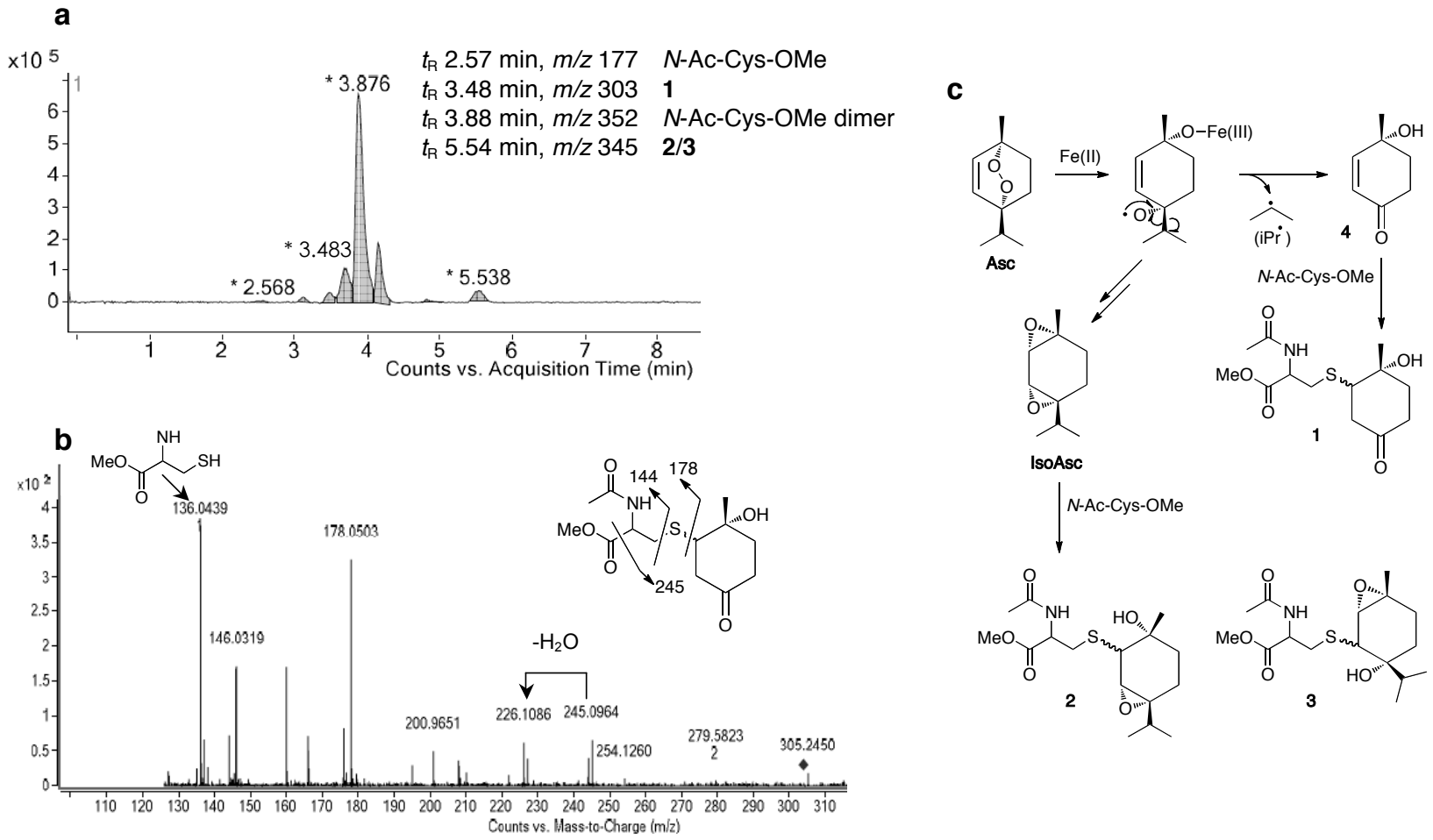
Fig. 2

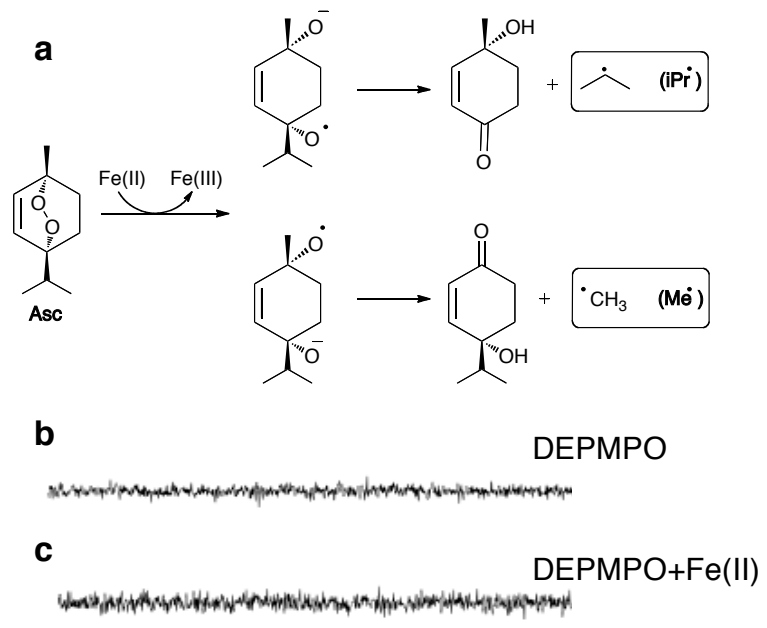

d

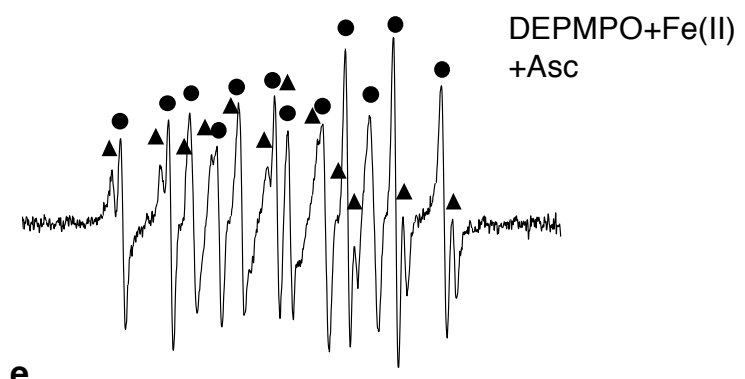

e

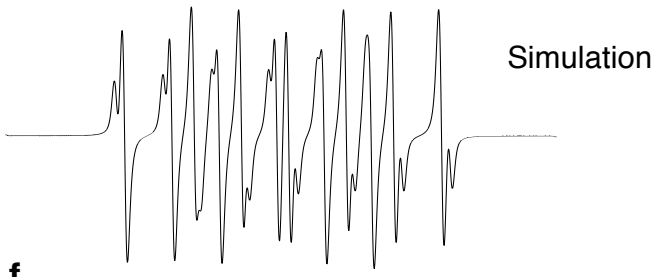

f

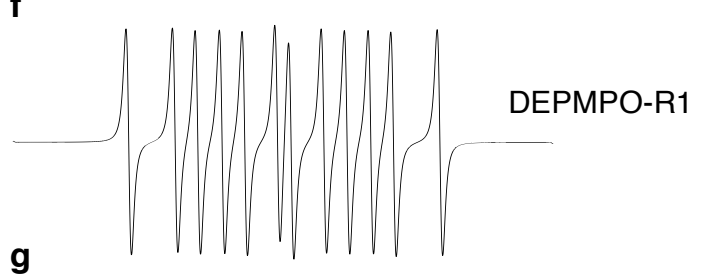

g

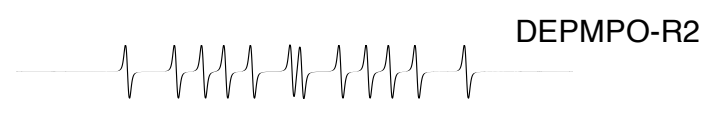

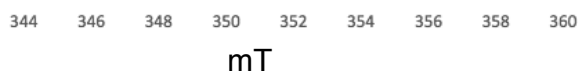


Fig. 3

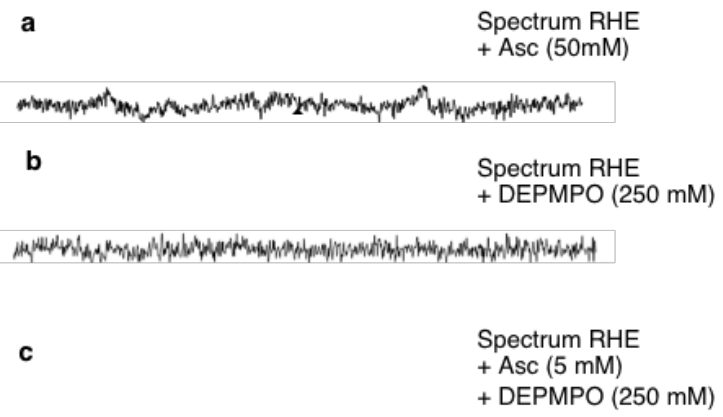

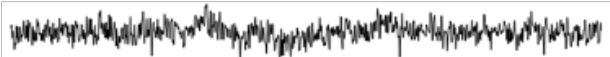
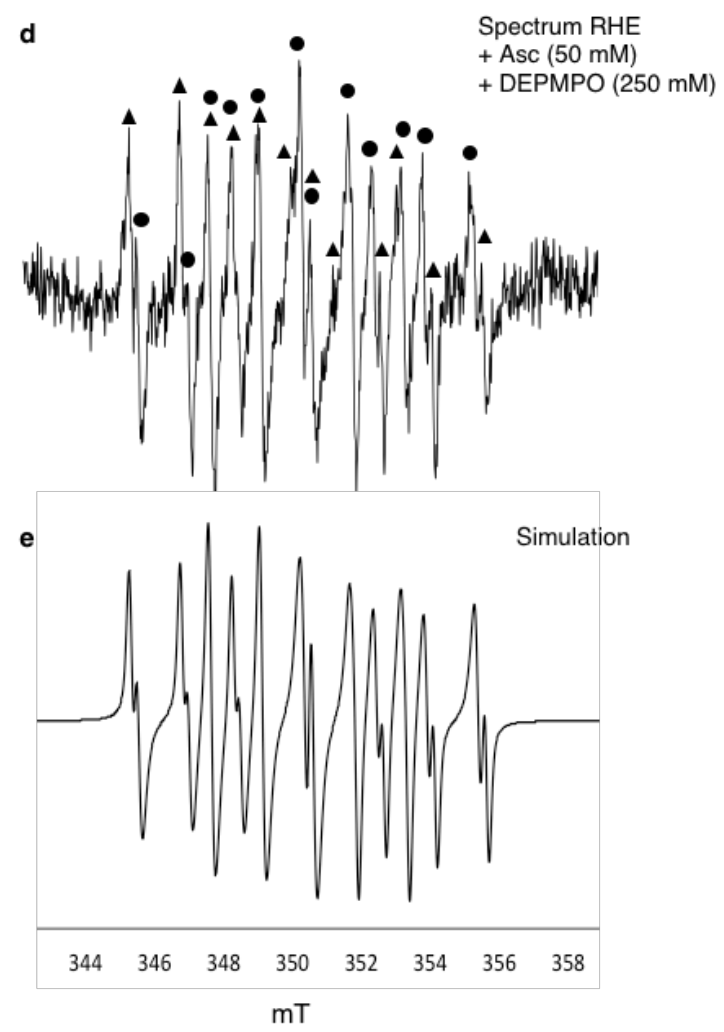
Fig. 4
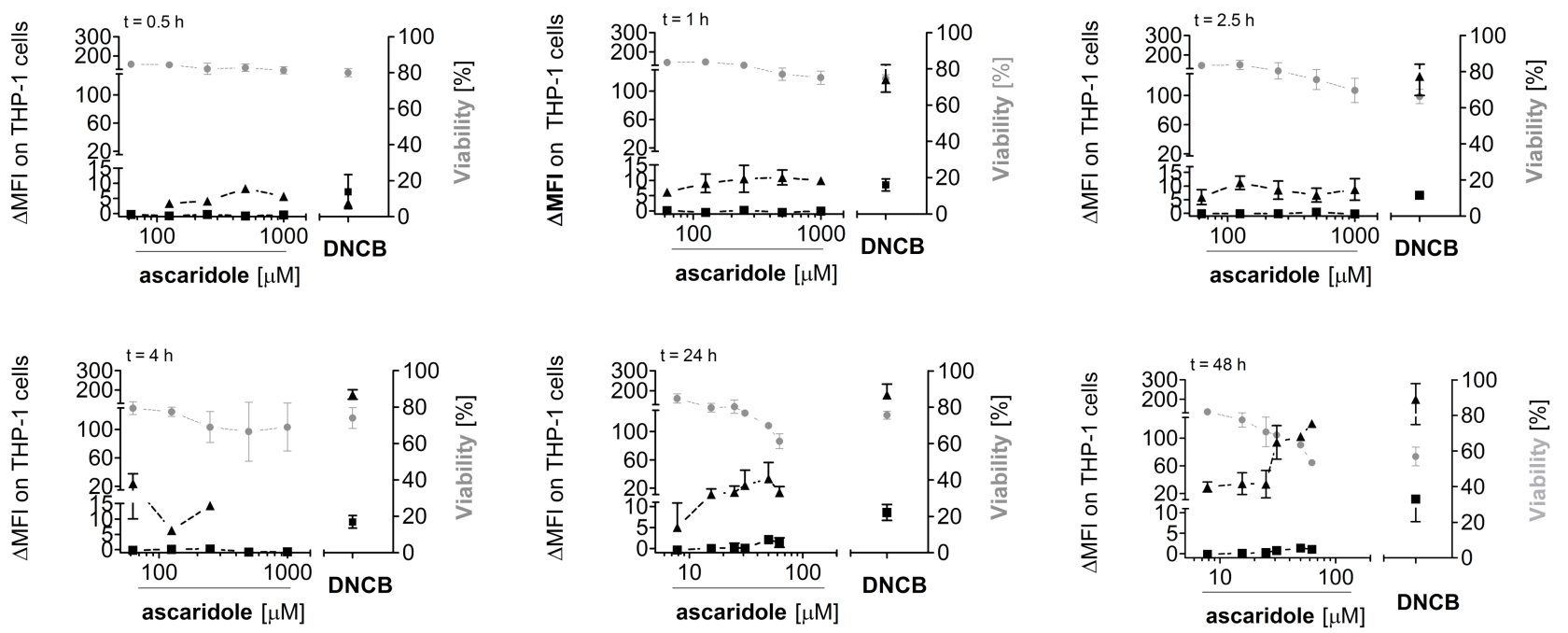
Fig. 5

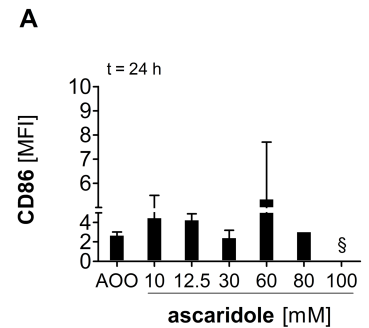

C
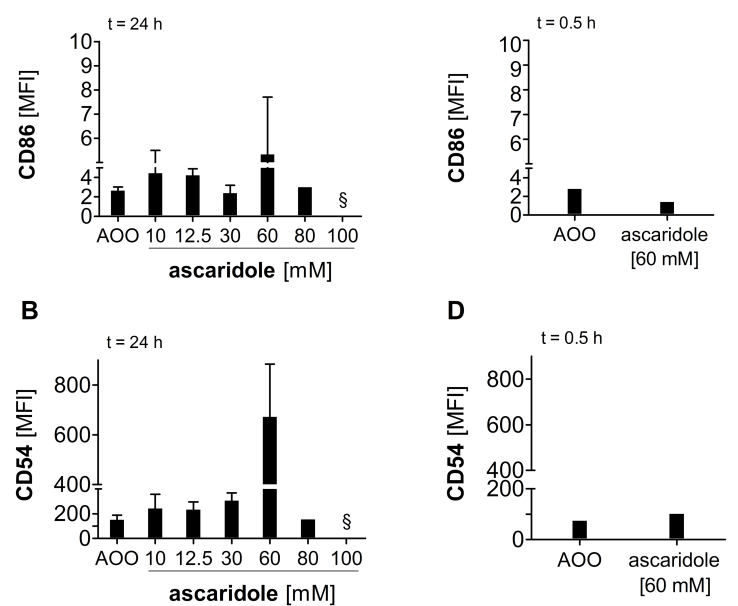